\title{
A Performance Analyst Comparison of ReactJS and AngularJS in the Front-End Website
}

\author{
Ilham Yusron ${ }^{1}$, Antoni Wibowo ${ }^{2}$ \\ ${ }^{1}$ Computer Science Department, BINUS Graduate Program - Master of Computer Science, \\ Bina Nusantara University, Jakarta, Indonesia 11480, ilham.yusron @ binus.ac.id \\ ${ }^{2}$ Computer Science Department, BINUS Graduate Program - Master of Computer Science, \\ Bina Nusantara University, Jakarta, Indonesia 11480, anwibowo@ binus.edu
}

\begin{abstract}
The process of developing a website is divided into two significant parts namely the development of the Front-End and Back-End sides. However, this research focused on the Front-End side development. One of the skills that a Front-End developer must have is JavaScript skills. Javascript is a programming language that can make websites more interactive. Nowadays, Javascript allows Front-End developers to play a broader role, such as the ability to set routers on URLs. The use of Javascript has increased since the use of frameworks such as ReactJS and AngularJS became more popular. AngularJS and ReactJS are the most popular debate among JavaScript developers. The debate often ended up being biased to one of the technologies. Developed by Google and Facebook, AngularJS and ReactJS are two popular technologies for developing an interactive one-page application. It is possible to make a comprehensive comparison between AngularJS and ReactJS because there are several points where they offer different things significantly. After conducting the research obtain the result that websites developed by using AngularJS had Size of codes lower than ReactJS. While websites developed by using ReactJS had larger Size of Code. When accesed on a browser, website was built using ReactJS had better performance and faster Response Time and Page Load Time than developed with AngularJS.
\end{abstract}

Key words : Website, Front-End, Javascript, ReactJS, AngularJS

\section{INTRODUCTION}

The process of website development is usually divided into two parts namely the development of the front-end and back-end. Both have different roles in website development process, but they complement each other to produce a good website and can provide a memorable experience for users. However, this research focuses on the Front-End website development. Common skills that a front-end developer must have are Image Editing, Cross Browser, HTML (Hypertext Markup Language), CSS (Cascading Style Sheets) and Javascript. Among all these skills, Javascript is the most interesting to discuss. Javascript is a programming language that make websites more interactive. The primary function of Javascript is to create websites interaction. Because of Javascript, we can create dialogue boxes, animations and many more. Currently, Javascript allows front-end developers to play a broader role, such as the ability to set routers on URLs. This is increasingly being used since the use of frameworks such as ReactJS and AngularJS has increased.

Javascript framework was developed when JQuery technology started on 2006. JQuery is a library that contains a collection of useful functions that will help programmers create websites easier. Then in 2010, the first version of AngularJS came out. It is an open-source javascript framework created by Google, where they provide the MVC architectural pattern (Model, View, Controller). With its easy-to-use, fast command implementation, and well-documented code, AngularJS has quickly gained popularity among website developers. AngularJS is more efficient than JQuery viewed from client-side. AngularJS also provides excellent performance on single-page web or SPA (Single Page Applications) [1]. In 2013, Facebook introduced ReactJS to solve scalability, performance, and optimization issues that were AngularJS weakness. ReactJS uses a different programming concept and switches to a unidirectional data flow. ReactJS code or syntax is cleaner, which makes it easy to learn and understand. That is why developers started to switch sides and choose ReactJS. Apart from that, thanks to JSX support, ReactJS also allows us to type HTML inside Javascript. This framework is used by many for developing a front-end interface for a web application. The Facebook application itself is built with ReactJS. It is also used by giant applications such as Instagram and WhatsApp. AngularJS is better than ReactJS in several attributes. However, on the performance side, ReactJS has better performance than AngularJS because of the virtual DOM implementation in ReactJS. AngularJS community is much bigger because ReactJS is still relatively new [8]. 
A reason and motivation that encouraged to do a research on this topic are because AngularJS and ReactJS are the most popular debate among front-end JavaScript developers. The debate often ends up biased on one technology or the other. AngularJS and ReactJS are two popular technologies for building interactive single page applications developed by Google and Facebook. Comprehensive comparisons between AngularJS and ReactJS are possible to perform because there are several points where they offer significantly different things. Namely creating the Front-End view from our application and in other places their functionality is imperfect unless it is assisted by third-party libraries or references. Using one of them is a question of whether AngularJS or ReactJS who is the better to solves the problem.

\section{RELATED WORKS}

\subsection{Website}

A website is a software that functions to display documents on a web that allows users to access the internet through software connected to the internet [2]. A website can also be described as a collection of pages that display information on text data, image data, animation data, sound, video or a combination of all of them, both static and dynamic which formed a series of interconnected buildings where each is connected to network pages (hyperlink). It is called static if the content of website information is constant, rarely changes, and the content of information is one directional, only provided by the website's owner. It is dynamic if the content of website information is always changing, and the content of the information is two-way interactive from the owner and website users [3].

A website is considered as a means of communication with an organization through a virtual environment. Several organizations have used websites to achieve organizational goals. One example is university admissions website. The university entrance website gets many visitors every day. The website contains many data, such as registration procedures, admission announcements, and new student registration. Also, a website is a medium between prospective new students and universities to accelerate the process of new students' admission [4].

\subsection{Front-End}

Front-End is part of a website application that allows direct interaction with users [5]. The Front-End of a website is the part that is immediately seen by the user. There are many Front-End frameworks and libraries based on JavaScript due to the innovation of the V8 engine. To find leading Front-End frameworks and libraries that are below industry standards, we collect usage data from Github, which is the largest Git repository hosting service globally. Github usage statistics could reflect global Front-End developer trends in each Front-End framework and library [6].

\subsection{Javascript}

JavaScript started as a simple non-professional scripting language in 1995 to support small-scale client-side logic in the earliest versions of the Netscape Navigator web browser. Now, the programming language has become widely spread that it attacks even the non-web domains that was previously reserved for classical programming languages [7].

JavaScript is a dynamic scripting language; it instructs the browser to make changes to page elements after loading the page. JavaScript is easy to learn. We only need a browser and a text editor to start writing and running code from Javascript [8]. JavaScript is a fundamental part of modern Web applications [9]. JavaScript is currently a programming language that is widely used in the creation of web applications and other applications. Several Javascript frameworks and libraries have appeared with their respective purposes and functions [10].

\subsection{ReactJS}

ReactJS is a type of JavaScript library that is used to build the reusable User Interface (UI) part of an Application. It encourages the creation of a reusable User Interface section, which shows the information that has evolved. It will powerfully change the information. ReactJS can also render the server using NodeJS, and it can control local applications using React Native. ReactJS actualizes one-way receptive information flow, which reduces the standard and is less demanding of reason than common authoritative information [11].

To make a mobile application display in ReactJS, you can use React Native. React Native is a Javascript framework that is used to create native applications that can run on the Android and iOS platforms. This framework was based on React JS, which is a Javascript framework created by Facebook that was used to create application displays that focused on mobile applications [12].

\subsection{AngularJS}

AngularJS is a Javascript framework used widely for the development of modern single-page web applications designed to support dynamic displays in applications [13]. AngularJS is a framework operated by Google; it helps build responsive sites. AngularJS is used to make a smooth web performance. AngularJS is a tool to develop the most suitable framework for application development today. It is fully extensible and works well with other libraries. Each feature can be modified or replaced to suit unique development workflows and feature requirements [14].

For developers who wanted to create mobile applications using AngularJS, they can use an interesting framework called 
Mobile Angular UI (User Interface) and Ionic. Ionic is a better platform to use for designing and building mobile applications. The development process is relatively fast, and developers have direct API access with Cordova. Ionic makes use of a CSS (Cascading Style Sheets) property called Syntactically Awesome Style Sheets (SASS) [15].

Table 1: Summary of Related Works

\begin{tabular}{|c|c|c|c|}
\hline Ref & Year & Title & Methodology \\
\hline$[5]$ & 2017 & $\begin{array}{c}\text { Evaluation of } \\
\text { Front-end JavaScript } \\
\text { Frameworks for } \\
\text { Master Data } \\
\text { Management } \\
\text { Application } \\
\text { Development }\end{array}$ & $\begin{array}{l}\text { Evaluated the most } \\
\text { significant } \\
\text { JavaScript } \\
\text { framework in terms } \\
\text { of developing } \\
\text { master data } \\
\text { management } \\
\text { (MDM) applications }\end{array}$ \\
\hline$[6]$ & 2019 & $\begin{array}{l}\text { Research and } \\
\text { analysis of the } \\
\text { front-end } \\
\text { frameworks and } \\
\text { libraries in } \\
\text { e-business } \\
\text { development }\end{array}$ & $\begin{array}{c}\text { Analyzed suitable } \\
\text { Javascript } \\
\text { framework for } \\
\text { building e-Business }\end{array}$ \\
\hline [8] & 2016 & $\begin{array}{c}\text { Comparative } \\
\text { analysis of angularjs } \\
\text { and reactjs }\end{array}$ & $\begin{array}{c}\text { Performed a } \\
\text { comparison based } \\
\text { on the attributes of } \\
\text { each framework }\end{array}$ \\
\hline [9] & 2018 & $\begin{array}{c}\text { AngularJS } \\
\text { performance: A } \\
\text { survey study }\end{array}$ & $\begin{array}{c}\text { Analyzed common } \\
\text { and technical causes } \\
\text { of AngularJS } \\
\text { performance issues }\end{array}$ \\
\hline$[10]$ & 2017 & $\begin{array}{c}\text { A comparative study } \\
\text { of versions of } \\
\text { JavaScript }\end{array}$ & $\begin{array}{l}\text { Made comparisons } \\
\text { by introducing the } \\
\text { features of each } \\
\text { javascript } \\
\text { framework }\end{array}$ \\
\hline [11] & 2018 & $\begin{array}{c}\text { React Framework } \\
\text { (Creating a Web } \\
\text { Application With } \\
\text { React Native) }\end{array}$ & $\begin{array}{l}\text { Introduced ReactJS } \\
\text { Framework and } \\
\text { building web using } \\
\text { ReactJS } \\
\end{array}$ \\
\hline [12] & 2018 & $\begin{array}{c}\text { Perbandingan } \\
\text { Phonegap Dan React } \\
\text { Native Sebagai } \\
\text { Framework } \\
\text { Pengembangan } \\
\text { Aplikasi Mobile }\end{array}$ & $\begin{array}{c}\text { Compared } \\
\text { frameworks for } \\
\text { developing mobile } \\
\text { applications }\end{array}$ \\
\hline [14] & 2016 & Angular JS & $\begin{array}{l}\text { Explained how to } \\
\text { use the Bootstrap } \\
\text { and Angular JS } \\
\text { framework }\end{array}$ \\
\hline [15] & 2018 & $\begin{array}{c}\text { Ionic Framework } \\
\text { with Angular for } \\
\text { Hybrid App } \\
\text { Development }\end{array}$ & $\begin{array}{l}\text { Created a hybrid } \\
\text { application that } \\
\text { could run on a- } \\
\text { ndroid, iOS, } \\
\text { windows platforms }\end{array}$ \\
\hline
\end{tabular}

\section{METHODOLOGY}

This study used a comparison method by creating two websites, each of which is built using AngularJS and ReactJS. The research methodology describes the method used in the comparative analysis of the performance of using AngularJS and ReactJS on the Front-End Website. The stages of the research methodology can be seen in Figure. 1.

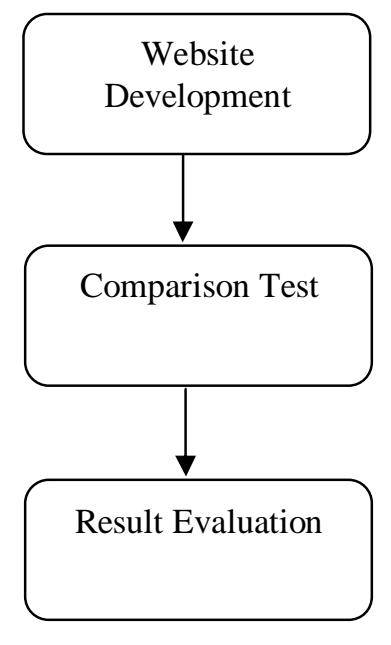

Figure 1: Methodology

\subsection{Website Development}

The first stage was the implementation stage. It included the implementation of both ReactJS and AngularJS frameworks by developing two websites using each of these frameworks. The application or website used as the research object was a website of services from a digital agency company. The sitemap and design of the website built can be seen in Figure 2 and Figure 3.

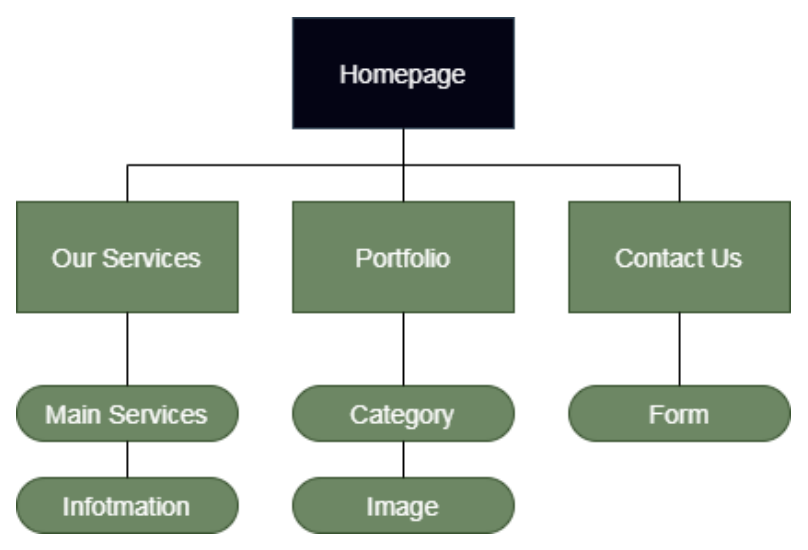

Figure 2: Sitemap Website 


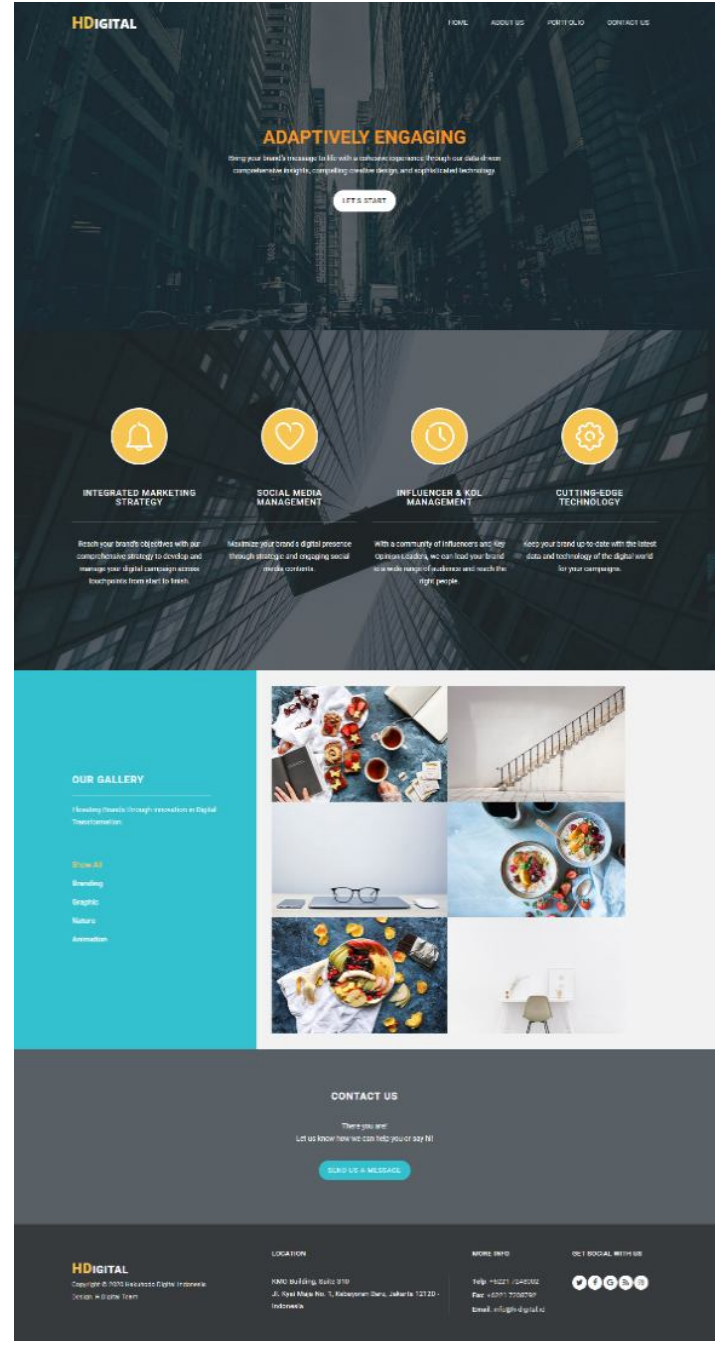

Figure 3: Website Design

\subsection{Comparison Test}

After the creation of the website was completed, then a performance test is carried out on the two websites that were previously built using the respective frameworks, namely AngularJS and ReactJS. Data retrieval will be carried out by conducting self-tests based on predetermined parameters to measure performance on the website. The parameters used in testing can be seen in Table 1 .

Table 1: Testing Parameters

\begin{tabular}{|c|c|c|}
\hline Parameters & Unit & Details \\
\hline Size of Code & Megabyte (MB) & $\begin{array}{c}\text { File Size before and } \\
\text { after rendering }\end{array}$ \\
\hline $\begin{array}{c}\text { Response } \\
\text { Time }\end{array}$ & Milisecond (ms) & $\begin{array}{c}\text { The time user needs } \\
\text { to send commands to } \\
\text { browser }\end{array}$ \\
\hline $\begin{array}{c}\text { Page Load } \\
\text { Time }\end{array}$ & Second (s) & $\begin{array}{c}\text { Times needed to } \\
\text { show every contents } \\
\text { of the website }\end{array}$ \\
\hline
\end{tabular}

Size of Code mentioned in this research is the size of the file before rendering and the file size of the rendering result. Response Time is a major factor to decide the rank of pages for faster access purposes. A faster website access is a factor that increases the usability of web pages. User availability will increase with web pages that can be accessed quickly [16]. Page Load Time and DOM Load Time are browser timings, not user timings, but they help set the stage for what a user experience is. Load testing is a performance testing technique in which the system response is measured under various load conditions. This test helps determine how the software behaves when several users access the software simultaneously [17].

The tool used to perform the test or the assessments was GTMetrix, GTMetrix is an automated software testing tool for measuring website performance. GTMetrix was built and developed by Gossamer Threads. This tool uses Google Page Speed and Yahoo YSlow as analysis engines. This tool is aimed to determine the performance of a website based on parameters such as page speed grade, YSlow class, page load time, page size, and the number of HTTP requests. The test results will be displayed with recommendations. Based on detailed information on the GTMetrix website, the results of the assessment are given in the form of a grade with a score in the form of a number. These scores are marked qualitatively with the letters A, B, C, D, E, and F, while the scores are marked quantitatively with numbers [18].

\section{EVALUATION RESULT}

The following is result from collecting the data with using a comparative test on the two websites that were previously developed using each framework.

\subsection{Size of Code Comparison Data}

Size of Code comparison testing was carried out manually by looking at the size of each website built using ReactJS and AngularJS before rendering and after rendering. The test results can be seen in Table 2 .

Table 2: Size of Code Comparison Data

\begin{tabular}{|c|c|c|}
\hline Framework & Before Rendering & Rendering Result \\
\hline ReactJS & $169 \mathrm{MB}$ & $9.53 \mathrm{MB}$ \\
\hline AngularJS & $399 \mathrm{MB}$ & $5.37 \mathrm{MB}$ \\
\hline
\end{tabular}

\subsection{Response Time Comparison Data}

Response Time comparison data was collected based on the components of Response Time including DNS Resolution Time, TCP Connection Time, HTTP Redirect Time, Time to First Byte, HTML Content Time and FullPage Object Load Time. The result of the test is shown in Table 3. 
Table 3: Response Time Comparison Data

\begin{tabular}{|c|c|c|}
\hline Component & ReactJS & AngularJS \\
\hline Blocking & $0 \mathrm{~ms}$ & $0 \mathrm{~ms}$ \\
\hline DNS Lookup & $5 \mathrm{~ms}$ & $1.7 \mathrm{~ms}$ \\
\hline Connecting & $47.4 \mathrm{~ms}$ & $53.7 \mathrm{~ms}$ \\
\hline Sending & $53.2 \mathrm{~ms}$ & $62.5 \mathrm{~ms}$ \\
\hline Waiting & $53.5 \mathrm{~ms}$ & $62.5 \mathrm{~ms}$ \\
\hline Receiving & $67.8 \mathrm{~ms}$ & $84.8 \mathrm{~ms}$ \\
\hline
\end{tabular}

\subsection{Page Load Time Comparison Data}

The Page Load Time comparison data was collected based on the components of Response Time including DNS Resolution Time, TCP Connection Time, HTTP Redirect Time, Time to First Byte, HTML Content Time and FullPage Object Load Time. The result is displayed in table 4.

Table 4: Page Load Time Data

\begin{tabular}{|c|c|c|}
\hline Component & ReactJS & AngularJS \\
\hline First Paint & $4.6 \mathrm{~s}$ & $2.15 \mathrm{~s}$ \\
\hline First Contentful Paint & $2 \mathrm{~s}$ & $4.12 \mathrm{~s}$ \\
\hline DOM Load Tine & $2.18 \mathrm{~s}$ & $4.35 \mathrm{~s}$ \\
\hline Onload & $3.78 \mathrm{~s}$ & $7.55 \mathrm{~s}$ \\
\hline Fully Load & $4.6 \mathrm{~s}$ & $7.99 \mathrm{~s}$ \\
\hline
\end{tabular}

\subsection{Result Analysis and Disscussion}

Based on the results of tests that were performed by observing the comparison of Size of Code, Response Time and Page Load Time of each framework a conclusion can be drawn. To find out which Javascript framework has better performance to be used to build the Front-End of a website, an analysis of the comparison result is needed. Table 5 and Figure 4 shows the analysis of the test's result.

Table 5: Test Result Analysis

\begin{tabular}{|c|c|c|}
\hline Parameter & ReactJS & AngularJS \\
\hline \multirow{2}{*}{ Size of Code } & $9.53 \mathrm{MB}$ & $5.37 \mathrm{MB}$ \\
\cline { 2 - 3 } & - & $\sqrt{ }$ \\
\hline \multirow{2}{*}{ Response Time } & $67.8 \mathrm{~ms}$ & $84.8 \mathrm{~ms}$ \\
\cline { 2 - 3 } & $\sqrt{ }$ & - \\
\hline \multirow{2}{*}{ Page Load Time } & $4.6 \mathrm{~s}$ & $7.99 \mathrm{~s}$ \\
\cline { 2 - 3 } & $\sqrt{ }$ & - \\
\hline
\end{tabular}

Notation: $\sqrt{ }$ stands for better performance.

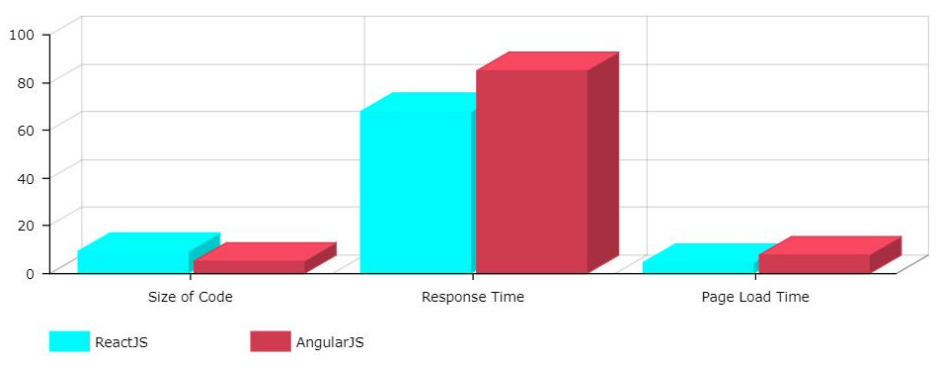

Figure 4: Graph of Test Result

Based on the testing, the Figure 4 shows that ReactJS tends to perform better when being accessed in web browser with Page Load Time score up to 4.6 s.

\section{CONCLUSION}

In the Size of Code test, the result showed that AngularJS has file size $169 \mathrm{MB}$, meanwhile ReactJS has file size 399MB. In terms of Response Time test, ReactJS was better than AngularJS. Time required for ReactJS in Response Time was 67.8ms, while for AngularJS was 84.8ms. In Page Load Time test, ReactJS was also better than AngularJS. The time took by browser to display all web page content built using reactJS was 4.6s while AngularJS took 7.99s to show the web page. While ReactJS had larger Size of Code, but when accesed on a browser, the website which was built by ReactJS had better performance and faster Response Time and Page Load Time than webite developed with AngularJS.

\section{FUTURE RECOMMENDATION}

Further research can be carried out by involving various different Javascript frameworks since the framework or library of Javascript continues to develop and also conducts performance tests when accessed on a mobile device.

\section{REFERENCES}

1. Chavare, N. N., \& Nadargi, A. V. (2016). Performance Comparison and Evaluation of jQuery with AngularJS. International Research Journal of Engineering and Technology, 2395-56. https://www.irjet.net/archives/V3/i5/IRJET-V3I5293.pdf

2. Nurmi, H. (2014). Membangun Website Sistem Informasi Dinas Pariwisata. Jurnal Edik Informatik, 1(2), 1-6.

3. Destiningrum, M., \& Adrian, Q. J. (2017). Sistem Informasi Penjadwalan Dokter Berbassis Web Dengan Menggunakan Framework Codeigniter (Studi Kasus: Rumah Sakit Yukum Medical Centre). Jurnal Teknoinfo, $11(2), \quad 30$. https://doi.org/10.33365/jti.v11i2.24

4. Putri, M. A., Hadi, H. N., \& Ramdani, F. (2018). Performance testing analysis on web application: Study case student admission web system. Proceedings - 2017 International Conference on 
Sustainable Information Engineering and Technology, SIET 2017, 2018-Janua(January 2019), 1-5. https://doi.org/10.1109/SIET.2017.8304099

5. Voutilainen, J. (2017). Evaluation of Front-end JavaScript Frameworks for Master Data Management Application Development. December, 4-6. https://www.theseus.fi/bitstream/handle/10024/138668/ Voutilainen_Jaakko.pdf?sequence $=1$

6. Xing, Y. K., Huang, J. P., \& Lai, Y. Y. (2019). Research and analysis of the front-end frameworks and libraries in e-business development. $A C M$ International Conference Proceeding Series, August, 68-72. https://doi.org/10.1145/3313991.3314021

7. Auler, R., Borin, E., De Halleux, P., Moskal, M., \& Tillmann, N. (2014). Addressing JavaScript JIT engines performance quirks: A crowdsourced adaptive compiler. Lecture Notes in Computer Science (Including Subseries Lecture Notes in Artificial Intelligence and Lecture Notes in Bioinformatics), 8409 LNCS, 218-237. https://doi.org/10.1007/978-3-642-54807-9_13

8. Kumar, A., \& Singh, R. K. (2016). Comparative analysis of angularjs and reactjs. International Journal of Latest Trends in Engineering and Technology, 7(4), 225-227. https://doi.org/10.21172/1.74.030

9. Ramos, M., Valente, M. T., \& Terra, R. (2018). AngularJS performance: A survey study. IEEE Software, 35(2), 72-79. https://doi.org/10.1109/MS.2017.265100610

10. Yadav, P. (2017). A comparative study of versions of JavaScript. 13(8), 2065-2073.

11. Application, W. E. B., React, W., \& Ka, C. (2018). React Framework (Creating a Web Application With React Native). International Journal of Recent Trends in Engineering and Research, 4(3), 642-646. https://doi.org/10.23883/ijrter.2018.4176.npvsn

12. Wijonarko, D., \& Aji, R. F. (2018). Perbandingan Phonegap Dan React Native Sebagai Framework Pengembangan Aplikasi Mobile. Jurnal Manajemen Informatika Dan Sistem Informasi, 1(2), 1. https://doi.org/10.36595/misi.v1i2.34

13. Chansuwath, W., \& Senivongse, T. (2016). A model-driven development of web applications using AngularJS framework. 2016 IEEE/ACIS 15th International Conference on Computer and Information Science, ICIS $2016 \quad$ - Proceedings. https://doi.org/10.1109/ICIS.2016.7550838

14. Sneha, A., \& Pushpanjali M., C. (2016). Angular Js. International Journal of Scientific \& Engineering Research,7(2), 73-76. http://www.ijser.org/researchpaper/Angular-JS.pdf

15. Waranashiwar, J., \& Ukey, M. (2018). Ionic Framework with Angular for Hybrid App Development. International Journal of New Technology and Research, 4(5), 263068.

16. Permatasari, D. I., Santoso, B., Ningtias, N., Atika, R., Maulana, I., Elektronika, P., \& Surabaya, N. (2019). Pengukuran throughput load testing menggunakan test case sampling gorilla testing. September, 2008-2014.
17. Permatasari, D. I. (2020). Pengujian Aplikasi menggunakan metode Load Testing dengan Apache JMeter pada Sistem Informasi Pertanian. Jurnal Sistem Dan Teknologi Informasi (JUSTIN), 8(1), 135. https://doi.org/10.26418/justin.v8i1.34452

18. Fryonanda, H., \& Ahmad, T. (2017). Analisis Website Perguruan Tinggi Berdasarkan Keinginan Search Engine Menggunakan Automated Software Testing GTmetrix. Analisis Website Perguruan Tinggi Berdasarkan, 4(2), 179-183. 